\title{
The Biggest Salt-Tongue Canopy of Central Iran
}

\author{
Mehran Arian', Hamideh Noroozpour ${ }^{2}$ \\ ${ }^{1}$ Department of Geology, Science and Research Branch, Islamic Azad University, Tehran, Iran \\ ${ }^{2}$ Department of Geology, Faculty of Science, Payame Noor University, Tehran, Iran \\ Email: $\underline{\text { mehranarian@yahoo.com }}$
}

Received 13 January 2015; accepted 8 February 2015; published 12 February 2015

Copyright (C) 2015 by authors and Scientific Research Publishing Inc.

This work is licensed under the Creative Commons Attribution International License (CC BY).

http://creativecommons.org/licenses/by/4.0/

(c) (i) Open Access

\begin{abstract}
One of the most interesting salt structures is salt-tongue canopy. The Central Iran basin has a few salt provinces and in this paper, morphotectonic concept of the salt-tongue canopy on the west of Garmsar city has been investigated. In this study, field data coupling with the salt tectonic-related factors to provide a position for salt rocks in the west Garmsar. Firstly, various geological factors such as faults, folds and roads were extracted and compiled. This is because the factors mentioned above play important role in the instability of the region. The results of this study showed that the salt extrusion from the Lower Red formation is severe. Further, it is evident that the shortening of main structures has had a great impact on it whilst the salt movements have occurred within Garmsar Syncline. Finally, the paper concluded that the salt-tongue canopy in the region has increased the rates of salt extrusion.
\end{abstract}

\section{Keywords}

Salt, Structure, Central Iran, Fault, Garmsar

\section{Introduction}

Salt-tongue canopies or Allochthonous salt sheets [1] are being categorized as types of salt structures. The main aim in this paper is to introduce an interesting salt structure that it has been named as the biggest salt-tongue canopy of Central Iran basin. The Central Iran basin has been located in the eastern part of the Turkish-Iranian plateau. The Turkish-Iranian plateau is one of two main plateaus in the Alpine-Himalayan collision system, the other being Tibet [2]. Garmsar city is the most important regions that it has connected Tehran to Semnan in north of Iran (Figure 1).

The Central Iran extends from eastern Anatolia to eastern Iran, and typically has elevations of 1.5 - $2 \mathrm{~km}$ 


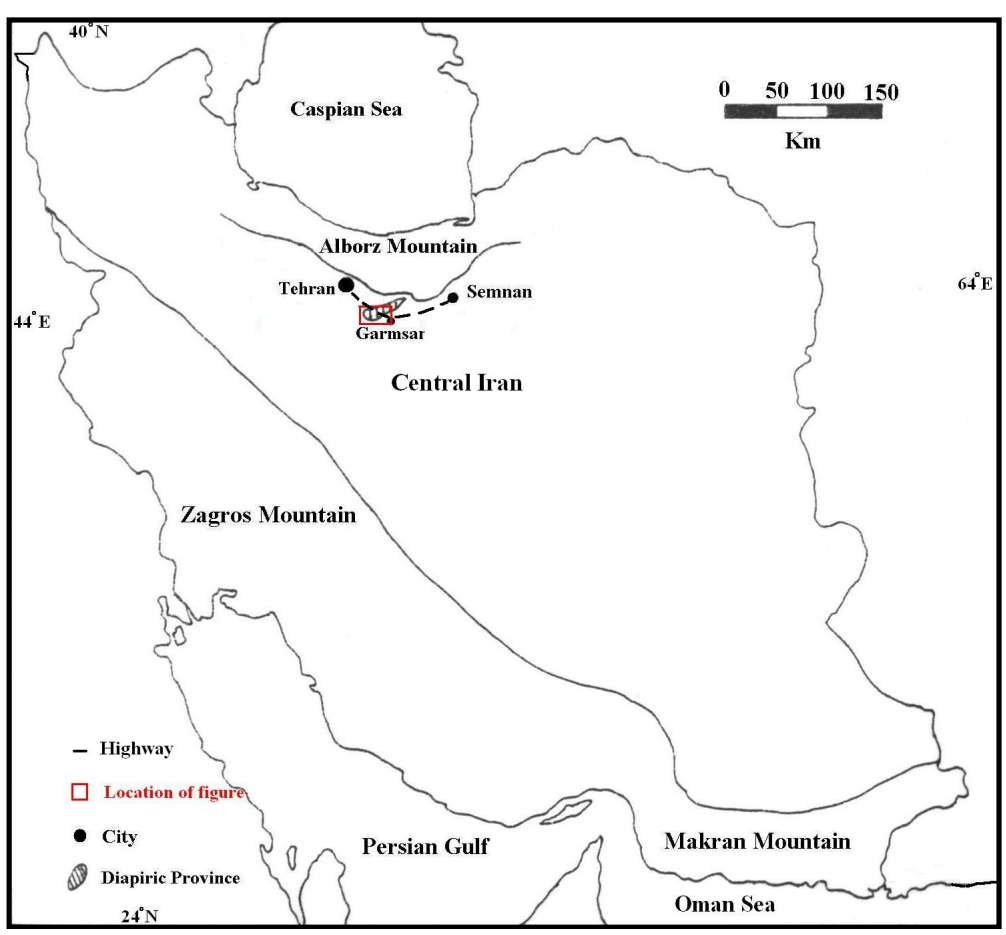

Figure 1. Geographical distribution of Garmsar diapiric province in Central Iran. Location of satellite image (Figure 3) is shown by red rectangle.

above mean sea level, decreasing to about $500 \mathrm{~m}$ in eastern Iran [3] and [4]. Roughly half of the present collision zone lies within the plateau, much of which is internally drained [5].

The basement of the plateau consists of microcontinents that were accreted to each other and Eurasia by the late Cretaceous or early Tertiary [6], interspersed with zones of ophiolites and melanges. Volcanism of late Cretaceous to early Miocene in Central Iran represent Andean type magmatism in southern Eurasia during the Neo-Tethyan subduction [7]. Volcanic and turbidite successions up to $5 \mathrm{~km}$ thick represent Eocene back-arc extension across Central Iran, the Alborz, the Lesser Caucasus and eastern Black Sea regions, north of the NeoTethyan subduction zone, and prior to Arabia-Eurasia collision [8].

Thick Eocene succession has been overlaid by commonly terrestrial deposits (the Lower Red Formation with Oligocene age), carbonate deposits (the Qom Formation with lower Miocene age) and terrestrial clastics (the Upper Red Formation) with middle Miocene age [9]. Then, several structural plains have been formed on above sedimentary succession and between major faults and/or anticlines by Late Cenozoic reorganization of the Arabia-Eurasia collision [10] and escape tectonics [11]. A dry bio-climate is prevalent on these plains, so they are called desert plains (Figure 2).

\section{Materials and Methods}

The Cenozoic salt deposits of Central Iran have two separate origins. The old type related to Upper Eocene deposits and Lower Red formation; and the new type related to Upper Red formation [12]. The salt domes of central Iran are mostly seen to the south of Semnan, north of Garmsar, southeastern and northwestern side of Qom, northwestern side of Saveh, and northeastern side of Ardekan, southwest side of Zanjan and north and east of Ravar [13].

Therefore, field investigation and remote sensing methods (by ETM+ Satellite Image) have considered for study of salt structures. Base on field work, origin of Garmsar region salt structures are distinguished as the Lower Red formation with Oligocene age (Figure 3, Figure 4) and an external trigger was confirmed by the stretched shape of salt dome.

In this area, salt has emerged by penetration along the Parchin fault (Figure 5), just as is common in the Zagros simple fold belt. Two geological cross sections have prepared through Garmsar salt structure that show po- 


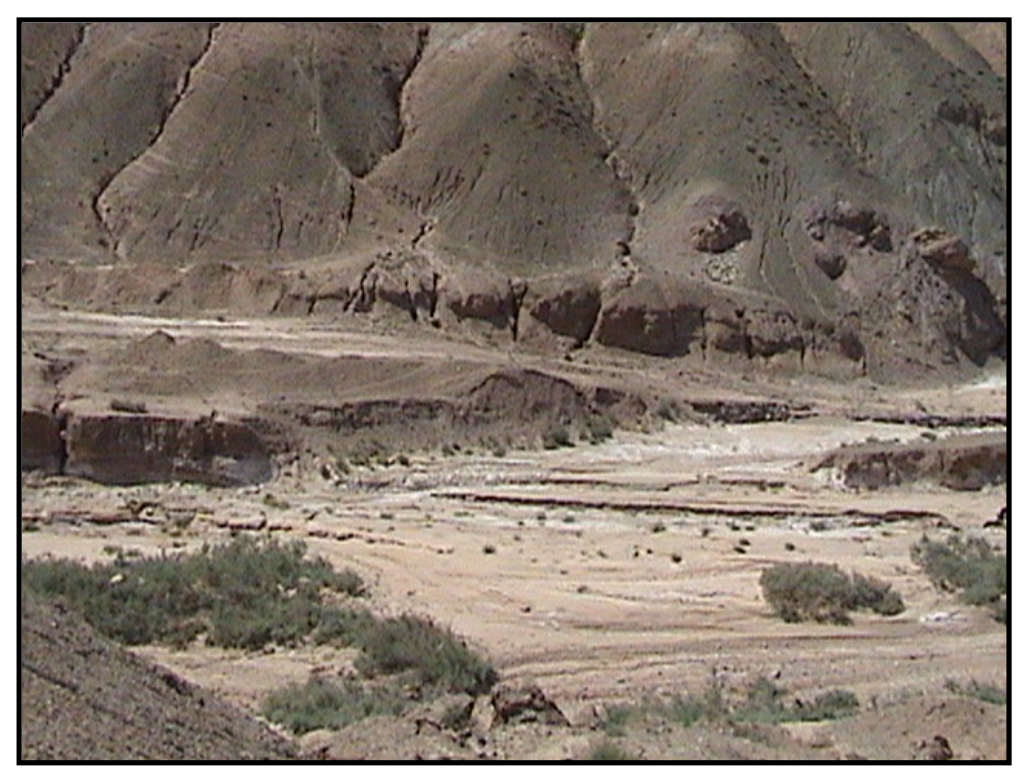

Figure 2. A desert plains in the northwest of Garmsar city.

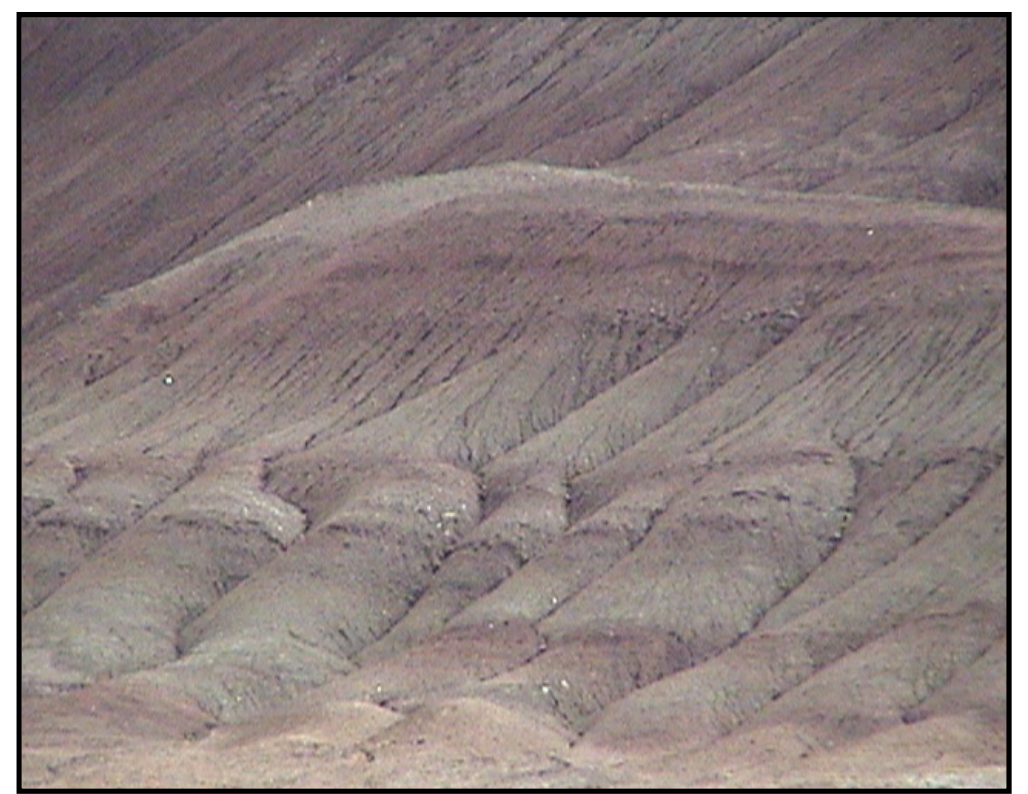

Figure 3. Terrestrial clastics members of the Lower Red formation in the west Garmsar.

sition of salt rocks (Black in Figure 6) in subsurface.

Also, according to remote sensing, Garmsar salt structure have comprised from a big salt-tongue canopy as two western and eastern lobes (with $130 \mathrm{~km}^{2}$ area) that connected together by a salt suture (Figure 7).

\section{Discussion and Results}

Garmsar basin is associated with a depression at the northwestern margin of Great Kavir. The salts of this province are of old type. The presence of salt, gypsum and sulfur reserves has resulted in an increase in mining activities in this area. Also, Cenozoic diastrophism has been caused deformational events in evaporite deposits that marked by [14]. Salt diapirism of Garmsar basin has orientations based on tectonic forces, effective in the Great Kavir-Northen Urmieh lake foreland basins [15]. It appears that tectonic processes are predominant compared to 


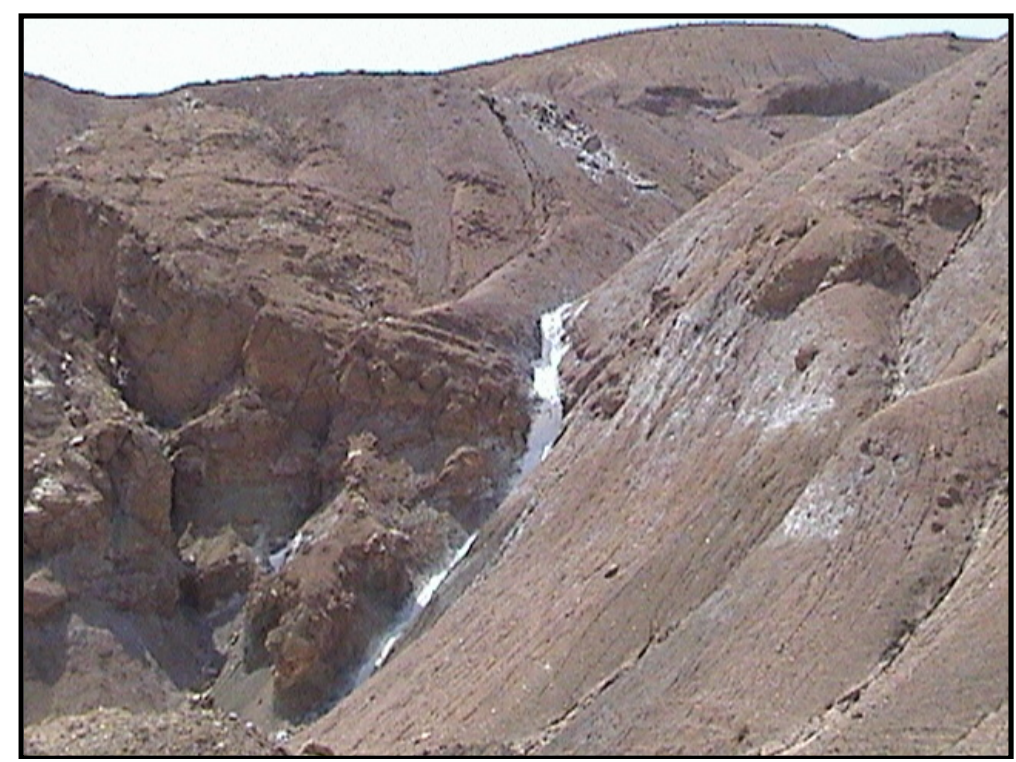

Figure 4. Lower Red formation or the origin of Garmsar region salt structure.

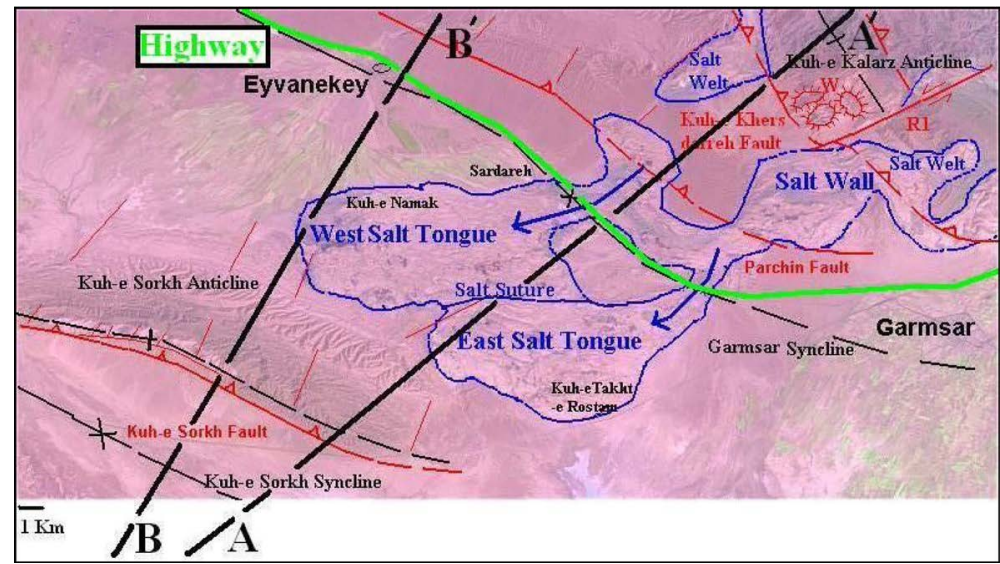

Figure 5. Interpreted ETM+ satellite image of salt-tongue canopy in the west Garmsar. Map located in Figure 1. Two Black lines (AA' and $\left.\mathrm{BB}^{\prime}\right)$ are trace of cross sections (Figure 6).

halokinesis in Central Iran. Because, the salt diapirs shapes and orientations follow the main structural trends in different basins of Central Iran.

The Tehran-Semnan highway have made on the northern parts of Garmsar salt-tongue canopy. Salt rocks have thinned in the north of western and eastern lobes (Figure 7). Therefore, there are not huge salt rocks and civil engineers can stable its movement by removing of evaporates. Because, these rocks not only do not have any root in subsurface, but also they are result of salt movement toward southwest. In the other words, the salt extrusion originated by the Lower Red formation and the shortening of surrounding anticlines such as Kuh-e Kalarz and Kuh-e Sorkh has a great impact on it whilst the salt movements have occurred within Garmsar Syncline between them.

From neotectonics point of view, study area is an active area that it has been revealed by calculation of geomorphic indices [16]-[19], structural analysis [20]-[22] and seismic risk analysis [23].

\section{Conclusion}

The Garmsar salt structure have comprised from a big salt-tongue canopy as two western and eastern lobes (with $130 \mathrm{~km}^{2}$ area) that connected together by a salt suture. Therefore, there are the biggest salt-tongue canopy of 


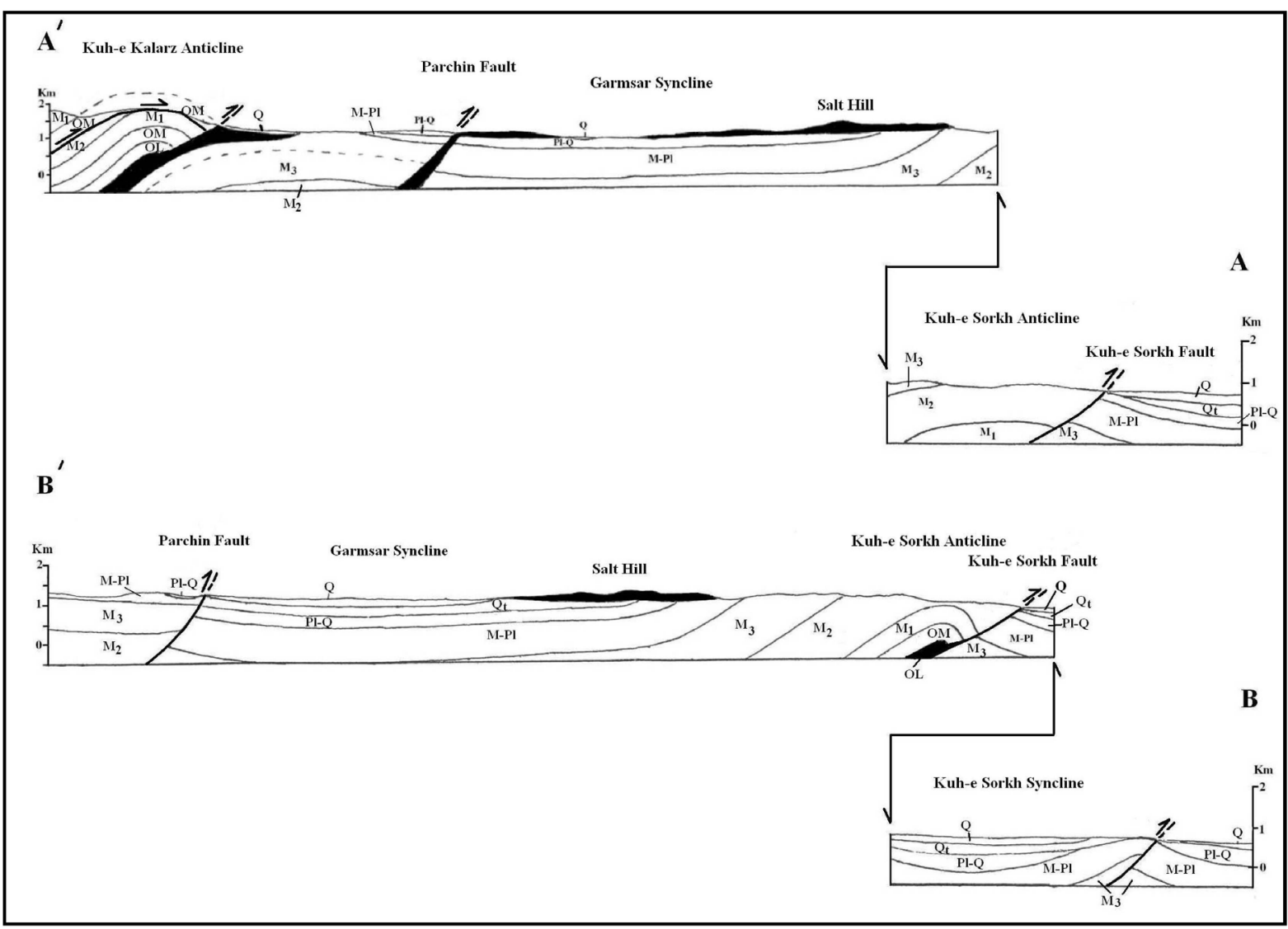

Figure 6. Two geological cross sections through Garmsar syncline.

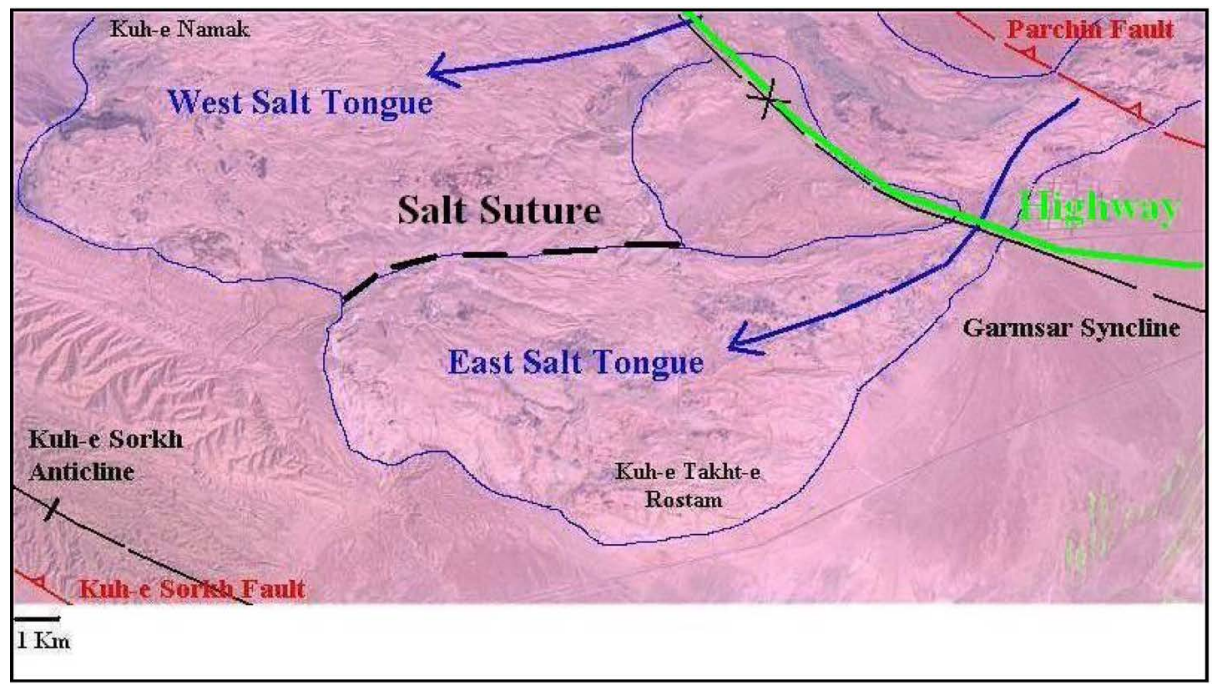

Figure 7. Interpreted ETM+ satellite image of salt-tongue canopy and its salt suture.

Central Iran basin that it has introduced in this paper.

Also, in this study, an attempt has been made to interpret the role of main structures in salt movement on the Tehran-Semnan highway. The study concludes that the major contributions for manmade hazards are mainly through the inappropriate road construction. Finally as a solution, my suggestion is removing of evaporates from around and beneath of the highway in where it is thin (Figure 5 and Figure 7). 


\section{Acknowledgements}

This work has funded by the Department of Geology, Islamic Azad University, Science and Research Branch, Tehran, Iran. Also, Special thanks to vice-president for research in Science and Research branch, Tehran.

\section{References}

[1] Hudec, M.R. and Jackson, M.P.A. (2006) Advance of Allochthonous Salt Sheets in Passive Margins and Orogens. American Association of Petroleum Geologist Bulletin, 90, 1535-1564.

[2] Dewey, J.F., Hempton, M.R., Kidd, W.S.F., Saroglu, F. and Sengor, A.M.C. (1986) Shortening of Continental Lithosphere: The Neotectonics of Eastern Anatolia, a Young Collision Zone. In: Coward, M.P. and Ries, A.C., Eds., Collision Tectonics, Geological Society of London Special Publications, 3-36.

[3] Qorashi, M. and Arian, M. (2011) Tectonics of Iran. Geologic Survey of Iran, Tehran, 336 p.

[4] Arian, M. (2011) Basement Tectonics and Geology of Iran. Asar Nafis Press, Qum, 300 p.

[5] Arian, M. (2012) Clustering of Diapiric Provinces in the Central Iran Basin. Carbonates and Evaporites, 27, 9-18.

[6] Sengor, A.M.C. (1990) A New Model for the Late Palaeozoic-Mesozoic Tectonic Evolution of Iran and Implications for Oman. In: Robertson, A.H.F., Searle, M.P. and Ries, A.C., Eds., The Geology and Tectonics of the Oman Region, Geological Society of London Special Publications, 797-831.

[7] Berberian, F., Muir, I.D., Pankhurst, R.J. and Berberian, M. (1982) Late Cretaceous and Early Miocene Andean-Type Plutonic Activity in Northern Makran and Central Iran. Journal of the Geological Society London, 139, 605-614.

[8] Brunet, M.F., Korotaev, M.V., Ershov, A.V. and Nikishin, A.M. (2003) The South Caspian Basin: A Review of Its Evolution from Subsidence Modeling. Sedimentary Geology, 156, 119-146.

[9] Stocklin, J. (1971) Stratigraphic Lexicon of Iran Part 1: Central, North and East Iran. Geologic Survey of Iran, Tehran, 338 p.

[10] Allen, M., Jackson, J. and Walker, R. (2004) Late Cenozoic Reorganization of the Arabia-Eurasia Collision and the Comparison of Short-Term and Long-Term Deformation Rates. Tectonics, 23, 16-32.

[11] Şengör, A.M.C. and Görür, N. (1985) Strike-Slip Faulting and Related Basin Formation in Zones of Tectonic Escape: Turkey as a Case Study. In: Biddle, K. and Christie-Blick, N., Eds., Strike-Slip Deformation, Basin Formation and Sedimentation, Special Publications, SEPM Society for Sedimentary Geology, Tulsa, Vol. 37, 227-264.

[12] Jackson, M.P.A., Cornelius, R.R., Craig, C.H., Gansser, A., Stocklin, J. and Talbot, J.C. (1990) Salt Diapirs of the Great Kavir, Central Iran. Geological Society of America, New York. 139 p.

[13] Pourkermani, M. and Arian, M. (1997) Salt Domes of Central Iran. Journal of Humanities University of Sistan and Baluchestan, 3, 29-41. (In Persian)

[14] Arian, M., Maleki, Z. and Noroozpour, H. (2011) Cenozoic Diastrophism and Deformational Events in the East-Central Alborz. Journal of Basic and Applied Scientific Research Faculty of Earth Sciences, 1, 2394-2400.

[15] Arian, M. (2013) Physiographic-Tectonic Zoning of Iran’s Sedimentary Basins. Open Journal of Geology, 3, $169-177$.

[16] Khavari, R., Arian, M. and Ghorashi, M. (2009) Neotectonics of the South Central Alborz Drainage Basin, in NW Tehran, N Iran. Journal of Applied Sciences, 9, 4115-4126. http://dx.doi.org/10.3923/jas.2009.4115.4126

[17] Arian, M. and Bagha, N. (2012) Active Tectonics of Tehran Area, Iran. Journal of Basic and Applied Scientific Research, 2, 3805-3819.

[18] Bagha, N., Arian, M., Ghorashi, M., Pourkermani, M., El Hamdouni, R. and Solgi, A. (2014) Evaluation of Relative Tectonic Activity in the Tehran Basin, Central Alborz, Northern Iran. Geomorphology, 213, 66-87. http://dx.doi.org/10.1016/j.geomorph.2013.12.041

[19] Arian, M. and Feizi, F. (2005) Application of Geomorphic Indices to the Assessment of Relative Tectonic Activity Levels in the Alborz-Central Iran Border Zone (from the East of Varamin to the East of Semnan). Journal of Sciences (Islamic Azad University), 15, 378-403.

[20] Arian, M., Pourkermani, M., Sistanipour, A. and Noroozpour, H. (2011) Kinematic Significance of Fold- and Fault-Related Fracture Systems in the Rafsanjan’s Northeast Highlands (Central Iran). Journal of Basic and Applied Scientific Research, 1, 3398-3406.

[21] Pourkermani, M. and Arian, M. (2001) Structural Geomorphology of Northeastern Kurdistan, Sistan and Baluchestan University. Journal of Humanities, 7, 37-48.

[22] Arian, M. and Pourkermani, M. (2004) Tectonic Elements of South Flank in the East-Central Alborz Mountain. Journal of Sciences (Teacher Training University), 4, 359-368.

[23] Feizi, F., Arian, A. and Rahmani, R. (2007) Seismotectonic Zoning in the Eastern Part of the Central Alborz. Journal of Sciences (Islamic Azad University), 17, 151-164. 